\title{
PARALLELS BETWEEN DAMAGES, WHICH ARE CAUSED AT SHOTS ELASTIC BULLETS FROM PISTOLS AND REVOLVERS, INTENDED FOR SELF-DEFENCE, AND DAMAGES WHICH ARE CAUSED FROM REGULAR SHOOTING-IRON
}

\author{
Mishalov V., Sukhiy V., Voychenko V., Kostenko E.
}

Resume. The resulted information is about complete enough accordance between damages, which are caused at shots elastic bullets from pistols and revolvers, intended for a self-defence, and damages which are caused from a regular shooting-iron. The indicated is determined that at shots from pistols and revolvers, intended for a self-defence, the same groups of injuring factors operate on the body of man, as at shots from a shooting-iron. On forming of damages properties a cartridge influence with an elastic bullet, features of structure of device for firing, property of organism of man and condition of external environment, which generates substantial differences between morphology of damages which appear at shots from devices for firing by elastic bullets and at shots from a shooting-iron.

Keywords: fire damages of clothes, an elastic bullet, additional factors of a shot.

\section{ПАРАЛЛЕЛИ МЕЖДУ ПОВРЕЖДЕНИЯМИ, КОТОРЫЕ ПРИЧИНЕНЫ ПРИ ВЫСТРЕЛАХ ЭЛАСТИЧНЫМИ ПУЛЯМИ ИЗ ПИСТОЛЕТОВ И РЕВОЛЬВЕРОВ, ПРЕДНАЗНАЧЕННЫХ ДЛЯ САМООБОРОНЫ И ПОВРЕЖДЕНИЯМИ ИЗ ШТАТНОГО ОГНЕСТРЕЛЬНОГО ОРУЖИЯ}

\author{
Мишалов В.Д., Сухий В.Д., Войченко В.В., Костенко Е.Я.
}

Резюме. В статье приведена информация о достаточно полном соответствии между повреждениями, которые причинены при выстрелах эластичными пулями из пистолетов и револьверов, предназначенных для самообороны, и повреждениями, которые причинены из штатного огнестрельного оружия. Указанное определяется тем, что при выстрелах из пистолетов и револьверов, предназначенных для самообороны, на тело человека действуют такие же группы травмирующих факторов, как при выстрелах из огнестрельного оружия. На формирование повреждений влияют свойства патронов с эластичной пулей, особенности строения устройства для стрельбы, свойства организма человека и условия внешней среды, которые порождают существенные отличия между морфологией повреждений, которые образуются при выстрелах из устройств для выстрелов эластичными пулями и из штатного огнестрельного оружия.

Ключевые слова: огнестрельные повреждения одежды, эластичная пуля, дополнительные факторы выстрела.

УДК: 340.66:616.-001.42-079.61-091.8

\section{КЛАСИФІКАЦІЯ ПНЕВМОСТРІЛЬНИХ УШКОДЖЕНЬ}

(СКозаченко I. М.

\section{Харківська медична академія післядипломної освіти}

Резюме. На підставі аналізу пневмострільної травми по матеріалах окремих бюро судово-медичної експертизи України за 2006-2015рp. із використанням раніше запропонованих термінології та понятійного апарату вперше опрацьовано уніфіковану класифікацію, яка містить 15 основ, необхідних для всебічної характеристики пневмострільних ушкоджень. Класифікація придатна для вивчення, опису, діагностики та статистичної обробки пневмострільних ушкоджень як судовими медиками, так і клініцистами.

Ключові слова: пневмострільні ушкодження, термінологія, класифікація, поняття, основи.

ВСТУП. Ушкодження, що заподіяні людині із сучасної пневматичної зброї (ПЗ), на теперішній час вивчені недостатньо, зокрема відсутня їх класифікація. Аналіз пневмострільної травми показав, що судовим медикам при наукових дослідженнях та виконанні експертиз живих осіб та трупів, а також клініцистам під час надання медичної допомоги пораненим із ПЗ потрібна класифікація пневмострільних ушкоджень, яка б містила їх всебічну характеристику та була б уніфікованою для вивчення, опису та оцінки цих ушкоджень, зокрема при формулюванні діагнозу та складанні звітів [1]. 
Мета роботи - опрацювання уніфікованої класифікації пневмострільних ушкоджень людини, придатної для їх вивчення, опису, діагностики та статистичної обробки.

Матеріал та методи дослідження. Під час дослідження вивчено та проаналізовано дані з 98 Висновків експерта та Актів судово-медичного обстеження (дослідження) живих осіб (76) і трупів (22) 3 приводу ушкоджень із П3, виконаних в окремих обласних бюро судово-медичної експертизи України у 2006-2015 рр., а також наукові праці вітчизняних та іноземних авторів, присвячені вивченню цієї проблеми судовими медиками (37 джерел), тлумачні, орфографічні та термінологічні словники [2-4]. Під час аналізу згаданих матеріалів розподіляли пневмострільні ушкодження у постраждалих за їх кількістю, локалізацією, видом, іншими морфологічними особливостями, а також за перебігом, наслідками та ступенем тяжкості.

\section{РЕЗУЛЬТАТИ ДОСЛІДЖЕННЯ ТА ЇХ ОБГОВОРЕННЯ.}

У досліджених матеріалах наведено дані з медичних карт, в яких пневмострільні поранення визначаються як «кульові» або «вогнепальні», хоча $з$ анамнезу відомо про поранення саме із ПЗ. Зрідка у згаданих медичних документах характер ушкоджень визначено як «пневмокульове поранення» та «поранення із пневматичної зброї». У Висновках експертів при дослідженні живих осіб та трупів переважно вживаються формулювання: «кульове поранення із пневматичної зброї», «пневмокульове поранення», «пневматичне поранення». Під час виконання експертизи живої людини, якщо клінічний діагноз визначений як «вогнепальне поранення», то й експерт пише теж саме. Це не відповідає затвердженій МОЗ України сучасній термінології та понятійному апарату пневмострільних ушкоджень тіла людини [5]. Необхідно також відмітити, що у XX класі МКХ-10 передбачена рубрика W34 для випадків, які пов’язані саме із П3 [6]. У зв'язку з цим, уявляється доцільним у звітності медичних закладів, у тому числі й бюро судово-медичної експертизи, відокремити пневмострільні ушкодження від вогнестрільних. Слід також зауважити, що позначення пневмострільних ушкоджень тіла люди як «вогнепальні» протирічить здоровому глузду, оскільки таке поранення можна завдати лише з вогнепальної зброї або пристрою 3 використанням енергії порохових газів. До того ж таке формулювання викликає непорозуміння у працівників слідства, тому що заподіяння ушкоджень із вогнепальної зброї має одні юридичні наслідки, а із пневматичної - зовсім інші. Слідчий, отримавши Висновок судового медика $з$ діагнозом «вогнепальне поранення» у разі застосування ПЗ, змушений з'ясовувати чи не було у злочинця ще й вогнепальної зброї, допитувати експерта та ін., тобто проводити зайві слідчі дії.

Існує думка, що пневмострільні ушкодження мають багато спільного з вогнестрільними, що ускладнює їх диференційну діагностику. Саме тому при роботі над класифікацією цих ушкоджень нами використано основні положення загальновизнаних класифікацій вогнестрільних ушкоджень [7]. При цьому застосували термінологію та понятійний апарат для пневмострільних ушкоджень з урахуванням також їх особливостей та відмінностей від вогнестрільних ушкоджень [5] . Деякі із 15-ти основ опрацьованої класифікації (табл. 1.) потребують поширених пояснень, які наведено нижче. Пневмострільні ушкодження/поранення поділено:

За видом снаряда:

- кульові: заподіяні всіма видами куль для ПЗ, а також кульок типу ВВ;

- осколково-кульові: такі, що виникають від дії як самої кулі, так і їі фрагментів; такі, що утворюються під час взаємодії кулі з твердою перешкодою або до контакту з тілом, або в самому тілі, наприклад, при влученні в кістку;

- колоті: заподіяні пневмострільними снарядами, яким хоча й притаманна колюча дія, але вони мають пневмострільне походження/характер (дротики, гарпуни, шприц-дротики, цвяхи до монтажних пневматичних пістолетів й т.п.);

- комбіновані: спричинені комбінованими кулями, що складаються з власне кулі (осердя) та піддона;

- атипові: спричинені снарядами, які не є штатними для ПЗ (кульки від підшипників, шрот для мисливської зброї, різноманітні саморобні снаряди та інші пристосовані предмети або речовини. 
КЛАСИФІКАЦІЯ ПНЕВМОСТРІЛЬНИХ УШКОДЖЕНЬ

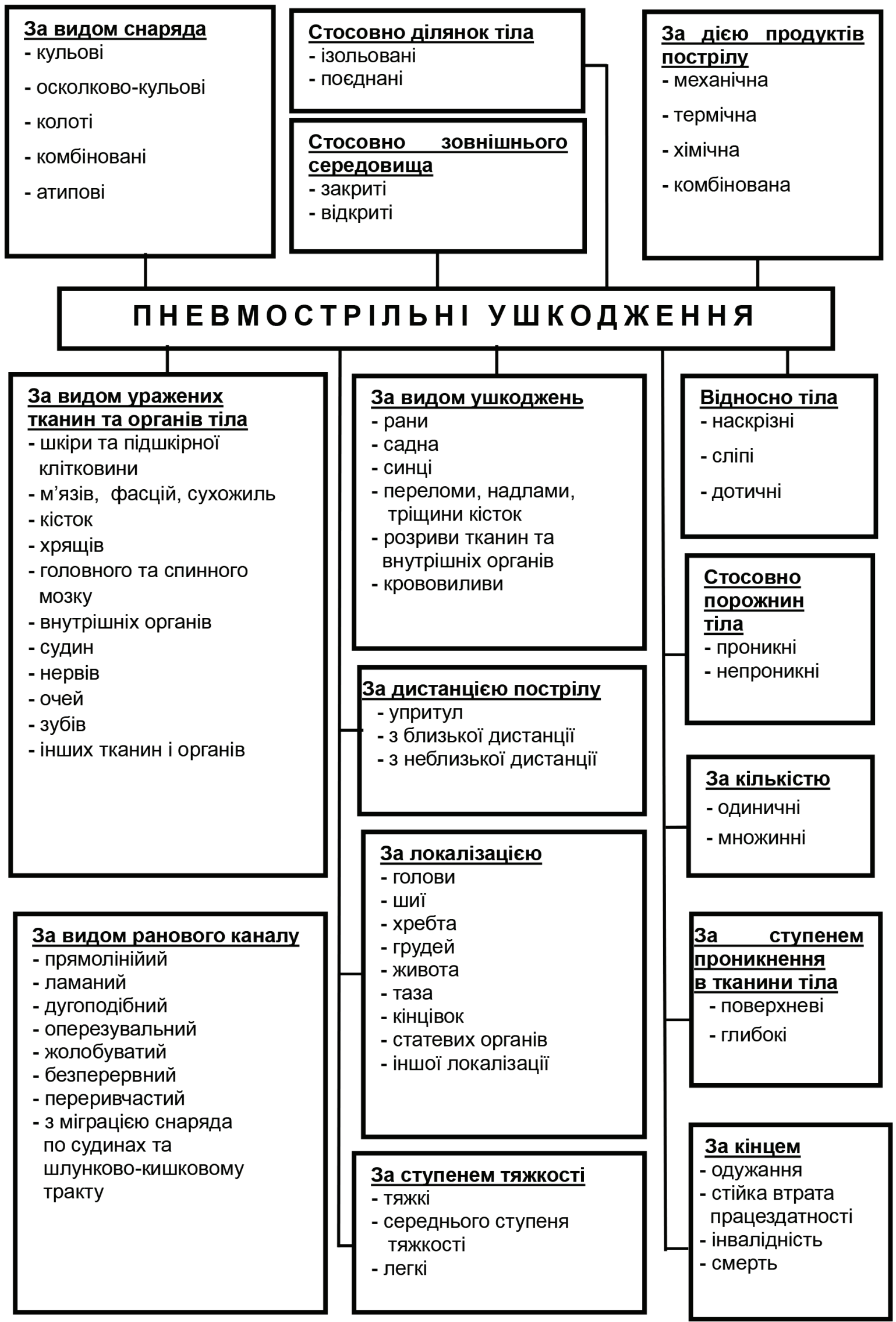


За дією продуктів пострілу:

- механічна: пневмострільний снаряд або його фрагменти (елементи), дуловий кінець зброї, повітря із каналу ствола, а також продукти згоряння світло-звукових куль здійснюють механічну дію на тіло, внаслідок чого виникають рани, садна, синці, підшкірна емфізема, втілення кіптяви у поверхневі шари шкіри, переломи, гематоми тощо;

- термічна: опіки від дії піротехнічного складу світло-звукових куль або бризок рушничного мастила при його надлишковому заливанні в ствол зброї для підвищення швидкості снаряда («дизель-ефект»);

- хімічна: місцева та загальна дія речовини, яка міститься у шприц-дротику;

- комбінована: від дії двох і більше продуктів пострілу, наприклад, механічної та термічної дії світлозвукових куль або механічної та хімічної дії при пострілі шприц-дротиком тощо.

За видом ушкоджень:

- рани: $з$ дефектом тканини, забиті, рвані, з підшкірною емфіземою, татуюванням порохом і втіленням кіптяви навколо та ін.;

- садна: поліморфні від контузійної дії снаряда, штамповані навколо вхідної рани від дії дулового кінця зброї при пострілі впритул (штанцмарки);

- синці: $з$ нечіткими контурами від контузійної дії снаряда, з чіткими контурами навколо вхідної рани, що повторюють форму дулового кінця зброї при пострілі впритул (штанцмарки);

- переломи кісток: лінійні, дірчасті, осколкові, крайові тощо;

- надлами (ушкодження кістки, що не проходять через усі її шари): лінійні,

утиснені (півсферичні, терасоподібні й т.п.), крайові тощо;

- тріщини (ушкодження однієї кісткової пластинки ): лінійні,

радіальні, концентричні;

- розриви окремих тканин та внутрішніх органів;

- гематоми й крововиливи в тканини, під оболонки, в порожнини тощо.

За кількістю:

- одиничні: не менше одного поранення (ушкодження) якоїсь ділянки тіла;

- множинні: три й більше поранення (ушкодження) однієї чи декількох

ділянок тіла.

За ступенем проникнення в тканини тіла:

- поверхневі: такі, де ушкоджені лише поверхневі шари тканин тіла,

наприклад, верхні шари шкіри, слизові оболонки, рогівка тощо;

- глибокі: такі, де ушкоджені глибокі шари тканин тіла.

Стосовно зовнішнього середовища:

- закриті: такі, що не сполучаються із зовнішнім середовищем (синці,

крововиливи, закриті переломи кісток тощо);

- відкриті: такі, що сполучаються із зовнішнім середовищем (підшкірна

емфізема, садна, рани, відкриті переломи кісток та ін.).

Відносно тіла:

- наскрізні: такі, що проникають через всю ділянку тіла або через всі

анатомічні утворення якого-небудь органа;

- сліпі: такі, що закінчуються в якій-небудь ділянці тіла або в стінці (товщі) якогось органа, при цьому в кінці ранового каналу звичайно залишається пневмострільний снаряд або його елементи (фрагменти);

- дотичні: відкриті ушкодження м'яких тканин або кісток у вигляді жолоба, що мають вхідний та вихідний кінець.

За видом ранового каналу:

- прямолінійний: у вигляді прямої лінії;

- ламаний: у вигляді лінії, що змінює свій напрямок;

- дугоподібний: у вигляді дуги;

- оперезувальний: рановий канал огинає якусь ділянку тіла (череп, груди);

- жолобуваті: у дотичних поранень;

- безперервний: рановий канал починається від вхідної рани і, ніде не перериваючись, закінчується або вихідною раною при наскрізних пораненнях, або снарядом у кінці ранового каналу при сліпих пораненнях;

- переривчастий: рановий канал не є суцільним (поєднані поранення, ушкодження порожнин тіла, порожнистих органів, легенів та ін.);

- $з$ міграцією снаряда: емболізм, міграція по судинах, шлунково-кишковому тракту, порожнинах та/або порожнистих органах із виведенням снаряда природним шляхом або з його виявленням у товщі якого-небудь органу, або вільне знаходження його в який-небудь порожнині чи порожнистому органі, просвіті судини, кишки тощо. 


\section{ВИСНОВКИ}

1. Запропонована класифікація сприятиме уніфікованому підходу судових медиків під час дослідження пневмострільних ушкоджень та виконання експертиз живих осіб і трупів, клініцистів - під час діагностики та лікування постраждалих, а також правників - під час оцінки висновків судово-медичних експертів.

2. Слід вважати доцільним у звітних документах окремо виділяти пневмострільні ушкодження.

3. Подальша систематизація пневмострільних ушкоджень $є$ перспективною, оскільки забезпечить необхідні методологічні засади для їх дослідження, що сприятиме більш грунтовному вивченню цієї проблеми.

\section{Література}

1. Козаченко I. М. Смертельна пневмострільна травма: структурний аналіз та морфологічні особливості ушкоджень Суд.-мед, експерт. - 2015. - № 2. - с. 89-93.

2. Великий тлумачний словник сучасної української мови [3 дод., допов. та CD] / [уклад. і голов. ред. В. Т. Бусел]. - К. : Ірпень ; Перун, 2009. - 1736 с.

3. Український орфографічний словник : близько 100000 слів / за ред.

А. О. Свашенко. - Х. : Прапор, 1997. - 845 с.

4. Російсько-український словник наукової термінології: Біологія. Хімія. Медицина / [С. П. Вассер, І. О. Дудка, В. І. Срмоленко та ін.]. - К. : Наук. думка, 1996. - 660 с.

5. Козаченко І. М. Сучасні термінологія, понятійний апарат і класифікації пневмострільних ушкоджень, пневматичної зброї та снарядів до неї (методичні рекомендації) / І. М. Козаченко // Міністерство охорони здоров'я України. - К., 2013. - 28 с.

6. Міжнародна статистична класифікація хвороб та споріднених проблем охорони здоров'я : десятий перегляд / за ред. І. В. Гармаша та ін. - К. : Здоров’я, 1998. - 1 (Ч. 2). - С. 505.

7. Попов В. Л. Судебно-медицинская баллистика / В. Л. Попов, В. Б. Шигеев, Л. Е. Кузнецов. - СПб. : Гиппократ, 2002. - $656 \mathrm{c}$.

\section{КЛАССИФИКАЦИЯ ПНЕВМОСТРЕЛЬНЫХ ПОВРЕЖДЕНИЙ}

\section{Козаченко И. Н.}

Резюме. На основании анализа пневмострельной травмы по материалам отдельных бюро судебно-медицинской экспертизы Украины за 2006-2015 гг. с использованием ранее предложенных терминологии и понятийного аппарата впервые разработана унифицированная классификация, содержащая 15 оснований, необходимых для всесторонней характеристики пневмострельных повреждений. Классификация применима для изучения, описания, диагностики и статистической обработки пневмострельных повреждений как судебными медиками, так и клиницистами,

Ключевые слова: пневмострельные повреждения, терминология, классификация, понятия, основания.

\section{CLASSIFICATION OF AIRGUN SHOT INJURIES}

\section{Kozachenko I. M.}

Summary. Based on the analysis of airgun shot trauma by materials some Bureau of Forensic Medicine of Ukraine for 20062015 , using the previously proposed terminology and conceptual apparatus first developed unified classification containing 15 th bases required for comprehensive response of airgun shot injuries. This classification is used for the study, description, diagnostics and statistical processing of airgun shot injuries as forensic doctors and clinicians.

Damage caused to a person from modern airguns, currently is not well understood, particularly not classified. Analysis of airgun shot trauma showed that forensic doctors in research and in carrying out examinations of living persons and dead bodies, as well as clinicians in the care of the wounded from the pneumatic weapon need classification of airgun shot injuries which would be determined by their comprehensive features and would unify exploration, description and evaluation of the damage, in particular in formulation of diagnosis and reporting.

Having studied and analyzed data from 98 of the Conclusions of experts and Acts of the forensic medical examination of living persons (76) and bodies (22) with damage caused by pneumatic weapons made in some Bureau of Forensic Medicine of Ukraine in 2006-2015 as well as scientific works of domestic and foreign authors, devoted to the study of the problem of forensic ( 37 sources), monolingual, spelling and terminology dictionaries. Airgun shot injuries were divided according to the following fifteen principles: the form of the projectile, the action product shot, location, type of injuries, type of damaged tissues and organs of the body, the number of injuries, the degree of penetration into the body tissues, relative to the external environment, relative of the body, with respect to cavities of the body, relative parts of the body, view of the wound channel, the severity of the injuries, the outcome of injuries, the distance of the shot. 
Conclusions: 1 . The proposed classification will promote unified approach to forensic doctors during the study of airgun shot injuries and performing examinations of living persons and dead bodies of clinicians in the diagnosis and treatment of victims, lawyers - in assessing the findings of forensic experts. 2. It is considered appropriate to mention in the accounting documents airgun damage separately. 3. Further systematization of airgun shot injuries will provide the necessary methodological bases for their research, which will contribute to a deeper study of this problem.

Keywords: airgun shot injuries, terminology, classification, concepts, bases.

\title{
ДІАГНОСТУВАННЯ АСПІРАЦІЇ ШЛУНКОВИМ ВМІСТОМ І ГЕНЕРАЛІЗОВАНОГО КРИПТОКОККОЗА У СУДОВО-МЕДИЧНІЙ ПРАКТИЦІ
}

\author{
() Сулосв К.М., ${ }^{1}$ Демченко І.А., Москаленко І.С., Матковская Л.Ц., \\ Опихайло М. С. \\ ДЗ «Дніпропетровська медична академія» МОЗ України ${ }^{1}$ \\ ОКЗ «Бюро судово-медичної експертизи Дніпропетровської ОДА»
}

Резюме: Аспірація може представляти негайну загрозу життю хворого. В залежності від характеру і кількості може викликати часткову або повну обструкцію дихальних шляхів. Серед хворих схильних до аспірації смертність від неї сягає 50 \%. Легенева інфекція після аспірації розвивається найчастіше протягом 2-14 діб. Аспіраційна пневмонія за етіологією у більшості випадків має бактеріальне походження. Значно рідше пневмонію і сепсис викликає мікотична інфекція. В зв’язку наведеними даними приводимо власне дослідження.

Ключові слова: судово-медична експертиза, діагностика, аспіраційна пневмонія, криптококкоз, ВІЧ, СНІД.

ВСТУП. Великий об'єм аспірата або наявність в ньому великих часток викликає механічну обструкцію дихальних шляхів, ателектази, застій бронхіального секрету, підвищуючи ризик настання смерті. Якщо хворий виживає виникнення пневмонії після аспірації залежить від кількості бактерій, що досягають термінальних бронхіол, їх вірулентності і від стану захисту нижніх дихальних шляхів. Статус захисної системи господаря визначає, буде мікроорганізм розмножуватися і викликати пневмонію або буде знищений факторами захисту. Аспіраційна пневмонія, як і сепсис за етіологією у більшості випадків має бактеріальне походження. Значно рідше пневмонію і системну запальну реакцію викликає мікотична інфекція. Серед грибів пневмонію частіше за усе викликає Histoplasma capsulatum, Coccidioides immitis i Blastomyces dermatitidis. Мікози виникають насамперед у людей 3 пригніченою імунною системою. До таких відноситься і кріптококкоз, що викликає Cryptococcus neoformans, який може розвиватися у здорової людини, але тяжкий перебіг спостерігається лише у людей з захворюваннями імунної системи, наприклад СНІД. Збудник може мати декілька форм. У патологічному матеріалі (тканинні недосконалі форми) має вигляд дріжджових клітин округлої форми діаметром 3-10 мкм, оточених прозорою желатиноподібною капсулою полісахаридної природи, шириною до 50 мкм (від ледь помітної до 2 діаметрів самої клітини). Міцелію не утворює. У досконалої (статевій) фазі криптококк має гіфи з великою кількістю кінцевих базидій. Тканинні форми знаходяться на різних морфологічних стадіях: початкова стадія (дрібні дріжджоподібні клітини), проміжна стадія (інкапсульовані форми), проміжна дегенеративна стадія (бескапсульні великі клітини). Капсула є основним фактором патогенності гриба, вона визначає здатність гриба до проникнення, розмноження і дисемінації, забезпечує збереження гриба в організмі хворого, так як гальмує фагоцитоз. Тому сильно інкапсульовані штами більш патогенні, ніж слабо інкапсульовані. Криптококк широко поширений в природі, його виявляють у посліді птахів. У висушеному стані може зберігатися протягом багатьох місяців. Криптококк виявляли на слизових оболонках здорових людей як сапрофіти. Інфікування людини відбувається повітряно-пиловим шляхом. Воротами інфекції в більшості випадків є верхні дихальні шляхи і легені, рідше спостерігається первинний криптококкоз шкіри, можливий ендогенний розвиток інфекції у здорових носіїв при зниженні у них імунного захисту. Захворювання частіше зустрічалося у осіб 40-60 років, чоловіки хворіли частіше. До групи ризику по захворюваності криптококкозом входять: ВІЛ - інфіковані особи, пацієнти, що отримували кортикостероідну терапію, хворі на лімфому, ідіопатичну CD4 Т-лімфоцитопенією, пацієнти, що перенесли трансплантацію органів і отримують імуносупресивну терапію, а також нерідко у хворих лімфогранулематозом, у яких також розвивається імунодефіцит. Тривалість інкубаційного періоду не встановлена. Найбільш характерним проявом криптококкозу є менінгоенцефаліт. Захворювання характеризується поступовим, малопомітним початком у вигляді нападів головного болю, частіше в лобовій області, які поступово посилюються, стають нестерпними, переміщаються в 